\title{
STUDENTS' ATITITUDE TOWARDS ASSIGNMENT AND ASSESSMENT IN READING: AN OVERVIEW OF E-LEARNING
}

\author{
SetianaSri Wahyuni Sitepu \\ Universitas Pamulang, Banten \\ dosen01057@unpam.ac.id
}

\begin{abstract}
E-learning is a program that has been implemented in Pamulang University since 2015. Despite the benefits of it as the medium for the students to learn with the absence of the teacher, it also gives beneficial or them to learn independently and creatively. However, as it is a latest for both teachers and students, the adversity cannot be avoided in terms of assignments and assessments. Therefore this study was aimed to reveal the students' attitude towards the assignments and assessments provided by the teacher for Reading in E-learning Program. The participants of this study were 40 students of reading class at the fourth semester of English Department of Faculty of Letters of Pamulang University. The data were collected by questionnaires and observation that the questionnaires were given to the students of reading subject while observation was conducted by observing reading assignment and assessment of E-learning program. The data from observation were analyzed by using qualitative measurement and the questionnaire used paper-based Likert-scale. The results showed that in spite of the difficulties in adapting in E-learning program they also have difficulties in understanding the materials and term of assessment. Futhermore, there is a negative attitude from them toward the assignment and assessment of reading in E-learning program.
\end{abstract}

Keywords: Attitude, Assignment, Assessment and E-Learning

\section{INTRODUCTION}

The developments of information and communication technology (ICT) have transformed the ways of teaching and learning. The use of ICT in language teaching and learning has increased significantly in recent years and today it fulfills to the needs of learning process. The computers take significant role in the learning process was awakened in 1970s and has grown up since then. Kenning (2007:105) suggests that two of the major advantages of ICT are that it helps learners to gain control of their own learning and help teachers individualize teaching. Elearning is one of the applications of ICT which enable the students to overcome the limitations of times, distances, and resources. According to Fee (2009), Elearning is an approach to learning and development, a collection of learning methods using digital technologies, which enable distribute and enhance learning. It can be understood that e-learning deals with the use of electronic media in transferring or supporting teaching and learning process to bring it into the classroom to empower learning. Today, the use of web to teach and learn is inevitable for both teachers and students. Online courses are becoming more and more necessary to dig knowledge. Thus, teachers should consider this approach in education and get prepared technically and pedagogically to take online teaching in consideration. The importance of E-learning is now a given fact and it can offer an alternative that is much faster, cheaper and potentially better.

Pamulang University has implemented and developed E-learning Program since 
2015 which is as one of the teaching methods. One of the subjects is reading skill that should be mastered by the students of English Departement. Dealing with the students' comprehension in reading, teacher delivers the assignment and assesses it. An assignment is a piece of academic work given to the students to produce as part of a course. When giving a reading assignment in a paper based form some students feel they have met their obligation to stare at the texts and many of them have low interest in reading. Besides the students feel bored when doing e- learning assignment. However, (Nabeel, 1994) in Al Mansour claims that in some English classes, the announcement of a reading assignment elicits moans and groans from students as they envision the long time it will require, the laborious task of looking up words' meanings in the dictionary. What makes matters worse is that after all the time and efforts; students fail to comprehend the text and no interaction for the assessment. However, assessment is an interactive process to know how well the students are learning. As (Brown 2004) says that a good teacher never ceases to assess students, whether those assessment are incidental or intended. It is important for both; teacher can improve the instruction and the students can learn from what they have done. (Brown 2004) states formative assessment is the most powerful type of assessment for improving students understanding and performance. As an interactive process assessment is used to make changes in the learning environment. . Since E-learning is new teaching approach in Pamulang University the assignments and assessments are conducted on e-learning. The research was aimed to observe students' attitudes toward assignments and assessments of reading in e-learning both in positive as well as the negative one. The finding would be used to improve the materials, assignments and assessments of the reading skill subject in e-learning program.

\section{METHOD}

This study used descriptive-qualitative method since it described the attitude of the students toward reading assignment and assessment in e-learning. Patton (1990:04) states'Qualitative findings grow out of three kinds of data collection:(1) In-depth, openended interviews(2) direct observation; and (3) written documents. To investigate students' attitude toward reading assignment and assessment in e-learning the data were collected from the questionnaire. The questionnaire was design by adapting the questionnaire model of e-learning of Pilli, Fanaeian and Al-Momani (2014). The indicators of the questionnaire were consisted of five factors; reading assessment, reading assignment, technology, perceive ease of use and students factor which were distributed into 26 question items with 21 positive statements and 5 negative statements (number 12,13,15,20 and 21). The data were submitted through five point Likert-Scale's questionnaire survey. The five points are strongly agree, agree, neutral, disagree, and strongly disagree that the highest point was strongly agree (5) and the lowest was strongly disagree (1). Beside questionnaire, the data were also collected through the documented observation that all students' answer and response towards the reading assignment in e-learning were used to find out their attitude toward the assessment and assignment of reading. Similarly, Brown (2007) said ,"one of the objectives of such observation is to assess students as much as possible without theory awareness(and possible consequent anxiety) of the observations, so that the naturalness of their linguistic performance will be maximized."

The sample was taken by using purposive sampling technique around 58 students from two classes reading and the 
questionnaires which were sent back were 40. Thus, the respondents of this research were 40 students who attended the reading class in Pamulang University. Before giving the questionnaires, all questions were explained to the respondents so they can easily complete the questionnaires with the relevant results.

\section{DISCUSSION}

The result of the study shows that the students favored reading assessment-as the first indicator- in e-learning that they can read the other students' work (item 3) and able to communicate with lecturer and others online (item 4). The percentages for both were $75 \%$ and $88 \%$ respectively. However, the students showed low attitude toward the transparency of personal assessment as stated in item 2 and gained the lowest result $(38 \%)$. On the second factorreading assignment- the response generally in 'neutral' that was reflected through their response which was range from $47 \%$ to $65 \%$. It means the students are not really certain about the reading assignment in elearning whether it helps them to understand the materials or not. However, the reading assignment presented in e-learning can motivate them even though only $41 \%$ respondents agreed with it. The same evidence also occurred in student factor that most of the respondent seemed 'neutral' which was ranged from $42 \%$ to $57 \%$ in item 22 to 26.

There were two factors that had negative and positive statements; technology and perceive ease of use factor. In technology factor, item number 11 and 14 are in positive tones while 12 and 13 in negative tone. The response toward the item number 11 and 14 were both neutral that it seems the students are not really sure they are capable enough using internet and whether the e-learning system give a quick response in peak hours or not. In perceive ease of using factor the response towards the highest percentage of responses were towards the statement I love to interact with e-learning $41 \%$ and I am pleased with the experience of using e-learning services $60 \%$. Table 1 shows that most of the statements in perceive ease of use were in 'neutral', it can be assumed that those who agreed must be the students who are accustomed to work using the internet or have an experienced using e-learning system.

\begin{tabular}{|c|c|c|c|c|c|c|}
\hline No. & $\begin{array}{c}\text { Item } \\
\text { Numbe } \\
\mathrm{r}\end{array}$ & Question Items & Agree $(\%)$ & $\begin{array}{r}\text { Neutral } \\
(\%)\end{array}$ & $\begin{array}{l}\text { Disagree } \\
(\%)\end{array}$ & $\begin{array}{c}\text { Total } \\
(\%)\end{array}$ \\
\hline 1 & 1. & $\begin{array}{l}\text { I can get the information } \\
\text { about my achievement in advance. }\end{array}$ & 45 & 37 & 18 & 100 \\
\hline 2 & 2 & $\begin{array}{l}\text { The available features allow } \\
\text { me to know my score more transparently and quickly. }\end{array}$ & 38 & 45 & 17 & 100 \\
\hline 3 & 3. & $\begin{array}{l}\text { I can read my classmates' } \\
\text { response as a comparison in assessing personal } \\
\text { achievement. }\end{array}$ & 75 & 23 & 2 & 100 \\
\hline 4 & 4. & $\begin{array}{l}\text { Discussion forum allows me to } \\
\text { communicate with lecturers and other classmates } \\
\text { related to materials discussion. }\end{array}$ & 88 & 10 & 2 & 100 \\
\hline 5 & 5 . & I understand the material presented in e-learning easily & 28 & 47 & 25 & 100 \\
\hline 6 & 6 & The material presented is clear and easy to understand. & 35 & 47 & 18 & 100 \\
\hline 7 & 7. & I can complete tasks and exercises easily and quickly. & 28 & 60 & 12 & 100 \\
\hline 8 & 8. & Work materials and instructions are easy to understand. & 30 & 65 & 5 & 100 \\
\hline
\end{tabular}




\begin{tabular}{|c|c|c|c|c|c|c|}
\hline 9 & 9. & $\begin{array}{l}\text { The different types of tasks and exercises motivate me } \\
\text { to learn. }\end{array}$ & 41 & 52 & 7 & 100 \\
\hline 10 & 10. & $\begin{array}{l}\text { The various types of assignments do not trouble me in } \\
\text { doing it. }\end{array}$ & 20 & 60 & 20 & 100 \\
\hline 11 & 11. & I have experience using internet. & 25 & 65 & 10 & 100 \\
\hline 12 & 14. & $\begin{array}{l}\text { The E-learning system responds quickly during peak } \\
\text { hours }\end{array}$ & 10 & 45 & 45 & 100 \\
\hline 13 & 16. & I love to interact with E-learning system. & 41 & 37 & 22 & 100 \\
\hline 14 & 17. & I enjoy using the E-learning system. & 31 & 50 & 19 & 100 \\
\hline 15 & 18. & $\begin{array}{l}\text { I am satisfied with the performance of E-learning } \\
\text { services. }\end{array}$ & 31 & 50 & 19 & 100 \\
\hline 16 & 19. & $\begin{array}{l}\text { I am pleased with the experience of using E-learning } \\
\text { services. }\end{array}$ & 60 & 20 & 20 & 100 \\
\hline 17 & 22. & $\begin{array}{l}\text { Using E-learning improves my effectiveness in } \\
\text { learning. }\end{array}$ & 33 & 57 & 10 & 100 \\
\hline 18 & 23. & Using E-learning increases my interest in learning. & 20 & 50 & 30 & 100 \\
\hline 19 & 24. & Using E-learning increases my motivation in learning. & 31 & 52 & 17 & 100 \\
\hline 20 & 25. & $\begin{array}{l}\text { Using E-learning allows me to complete tasks more } \\
\text { quickly. }\end{array}$ & 38 & 50 & 12 & 100 \\
\hline 21 & 26 & $\begin{array}{l}\text { Using E-learning makes it easy for me to understand } \\
\text { course material. }\end{array}$ & 18 & 42 & 40 & 100 \\
\hline \multicolumn{3}{|c|}{ Total } & 766 & 964 & 370 & \\
\hline \multicolumn{3}{|c|}{ Average } & $37 \%$ & $46 \%$ & $18 \%$ & 100 \\
\hline
\end{tabular}

Table 2 displays the students' response toward the attitude of reading assignment and assessment in e-learning in negative statements. The items number 12 and 13 are parts of technology factor while items 15, 20 and 21 are from perceive ease of use factor. In responding to the statement regarding the time that have been spent by the students using e-learning for reading subject, $48 \%$ agreed that they have spent much time and $70 \%$ agreed that they have spent much time than they expected before. Regarding the perceive use factor, most students agreed that they have difficulties in learning reading using e-learning. There were $75 \%$ out of 40 students agreed that they have difficulties in understanding the reading materials in e-learning. Meanwhile, items number 20 and 21 which dealt with using elearning $51 \%$ agreed that they felt helpless and unhappy using e-learning and $70 \%$ agreed that the anxiety was caused by the difficulty in getting the e-learning access.

Table 2. The Percentage of Students' Response in Negative Statements

\begin{tabular}{c|l|r|r|r|r}
\hline $\begin{array}{c}\text { Item } \\
\text { Number }\end{array}$ & \multicolumn{1}{|c|}{ Question Items } & $\begin{array}{c}\text { Agree } \\
(\%)\end{array}$ & \multicolumn{1}{c|}{$\begin{array}{c}\text { Neutral } \\
(\%)\end{array}$} & \multicolumn{1}{c}{$\begin{array}{c}\text { Disagree } \\
(\%)\end{array}$} & \multicolumn{1}{c}{$\begin{array}{c}\text { Total } \\
(\%)\end{array}$} \\
\hline 12. & $\begin{array}{l}\text { Using an E-learning system really spends } \\
\text { my time. }\end{array}$ & 48 & 30 & 22 & 100 \\
\hline 13. & $\begin{array}{l}\text { Using E-learning system, I end up } \\
\text { spending more time than I have planned. }\end{array}$ & 70 & 25 & 5 & 100 \\
\hline 15. & $\begin{array}{l}\text { While using an E-learning system, I have } \\
\text { problems in understanding the material. }\end{array}$ & 75 & 23 & 2 & 100 \\
\hline 20. & $\begin{array}{l}\text { I feel helpless and unhappy when asked to } \\
\text { use e-learning }\end{array}$ & 51 & 25 & 24 & 100 \\
\hline 21. & $\begin{array}{l}\text { The difficulty of getting access often } \\
\text { frustrates me. }\end{array}$ & 70 & 7 & 23 & 100 \\
\hline Total & & $63 \%$ & $22 \%$ & $15 \%$ & 100 \\
\hline Average & & & & \\
\hline
\end{tabular}


The results from the analysis both the questionnaire and the observation found that the students' attitude towards reading assignment and assessment in e-learning were not quite satisfied overall since most responses were neutral. However, the results from each indicator of questionnaire were different that students 'attitude towards reading assessment were considerably good or positive that the students are able to assess themselves and learn from others in online mode. However, they were not really satisfied with the online material that the response was in neutral of approximately $55.2 \%$. The observation towards online reading assignment has proved that some of the questions were false and even left empty. This might be due to the limited space for uploading the materials that the lecturer could not provide enough explanation and sample, so the students could not understand the materials.

Table 3. The Result of Students' Attitude towards Reading Assignment And Assessment in Elearning

\begin{tabular}{l|r|r|r|r|r|r}
\hline \multirow{2}{*}{\multicolumn{1}{c|}{ Indicator }} & \multicolumn{4}{c|}{ Positive Attitude } & \multicolumn{3}{c}{ Negative Attitude } \\
\cline { 2 - 7 } & $\begin{array}{c}\text { Agree } \\
(\%)\end{array}$ & $\begin{array}{c}\text { Neutral } \\
(\%)\end{array}$ & $\begin{array}{c}\text { Disagree } \\
(\%)\end{array}$ & $\begin{array}{c}\text { Agree } \\
(\%)\end{array}$ & $\begin{array}{c}\text { Neutral } \\
(\%)\end{array}$ & $\begin{array}{c}\text { Disagree } \\
(\%)\end{array}$ \\
\hline Reading Assessment & 61.5 & 28.75 & 9.75 & & & \\
\hline Reading Assignment & 30.3 & 55.2 & 14.5 & & & 13.5 \\
\hline Technology & 17.5 & 55 & 27.5 & 59 & 27.5 & 16.3 \\
\hline Perceive Ease of Use & 40.7 & 39.3 & 20 & 65.3 & 18.4 & \\
\hline Students & 28 & 50.2 & 21.8 & & & $15 \%$ \\
\hline Total & $37 \%$ & $46 \%$ & $18 \%$ & $63 \%$ & $22 \%$ & \\
\hline
\end{tabular}

The same result also found in indicator students factor that $50 \%$ of the students felt unease with e-learning and confuse whether they had learnt and used the time effectively but shows a greater response in the statement that their motivation increased while using e-learning. The result in indicator technology factor is correlated with the result in students and perceive ease of using factor. Since about $59 \%$ of the students attitude tend to be negative-three statements in negative tone- and only $17.5 \%$ in positive attitude that indicates although the students were fascinated with the technology used in e-learning however they were doubt that their work would be satisfied enough (table 3 ). It can be assumed that the familiarity of the program and equipment may bother them and the trouble that they had to access the e-learning especially in peak hours. It is also supported by the result of indicator in perceive ease of use that $65.3 \%$ of students had negative attitude toward getting the e-learning access and $40.7 \%$ had positive attitude (table 3 ). It indicates that the e-learning systems need to be improved and upgrade the bandwidth so the students can have a better access while using e-learning.

The observation which was conducted by observing the classroom discussion forum in e-learning it was found that the students tended to give comment that they have to read the text several times to grasp the idea. It indicates that the materials were quite to be understood by them. They also commented that there were too many exercises and some of the items were difficult to be answered by them. Those finding are correlated with the students' response in questionnaire that in reading assessment factor that the students choose the neutral attitude which means they did not definitely say the agreement or 
disagreement towards the statement. These findings approved that the materials published in e-learning need to be revised to a better one by giving more explanation and example. Thus, the students need to be familiarized with the types of reading assignments since the variations of assignments actually help improving their reading comprehension.

Generally, it can be said that the students have negative attitude towards reading assignments and assessments in elearning as shown in table 3. Comparing the result of the students' response in negative and positive statements, there were $63 \%$ students had negative statements and $37 \%$ had positive attitude. However, the percentage of the students' response for each indicator should also be considered, hence the lecturer could improve and provide the assignment and assessment of reading becomes much better in the future.

\section{CONCLUSION}

From the finding and discussion it can

be concluded that the students' attitude

\section{REFERENCES}

AlMansour ,S,Nasser 1994"The effect of teacher's storytelling aloud on the reading comprehension"Language and Translation Journal 23/2,69-76.

Anderson, Gary. 1998. Fundamental of Educational Research. Philadelphia:

USA The Falmer Press, Taylor

Brown,D,H,2007. Teaching by Principles : An interactive Approach to language Pedagogy San Francisco State University : Longman Com, p 447.

Brown,D,H.1994.Language assessment : Principles and classroom practice. San FranciscoState University : Longman Com, pp 4-5.

Brown,D,H.1994.Language assessment : Principles and classroom practice. San towards reading assignments and assessments of reading in e-learning are negative. However, the judgment may not simply because the students reject or do not like e-learning either, however there was an assumption that the students have familiar with the information communication technology (ICT) using internet or plainly say that in this modern era they should be very familiar and are capable in using ICT. The result of negative attitude might be caused by the unfamiliarity of elearning and the comfortableness of learning in the classroom with paper-based assignment.

The results of this study help the lecturers to design the materials and assignments of reading in e-learning much better than the previous one. The relatively neutral response in five indicators of questionnaire of attitude might come from a number of factors that open the chance for the future research. Regarding the campus policy of e-learning, have opened the possibility to examine best practices and better pedagogical designs for e-learning.

Francisco State University : Longman Com, p 6.

Fee, K. (2009).Delivering E-Learning. Philadelphia: Kogan Page Limited.

Gay, Mills \&Airasian. (2009). Educational Research: Competencies for Analysis and Application. New Jersey: Pearson Education Inc.

Kenning, Marie-Madeleine. 2007. ICT and Language Learning Chippenham and East bourne: Antony Rowe Ltd.

Mcworther, Kathleen. 1986. Guide to College Reading. London: Longman Group

Mikuleky, Beatrice S and Linda Jefries. 2007. Advance Reading Power, New York: Addison-Wesley Publishing Company 
Miller, D. (2000). Reading with Meaning. Portland me: Stenhouse Publishers.

Paris, Paul G. 2004. E-Learning: A study on Secondary Students Attitudes towards Online Web Assisted Learning International Education Journal Vol .5, No 1, 2004 http://iej.cjb.net 98, The Flinders University of South Australia pparis@adam.com.au

Patton, Michael 2002. Qualitative Research and Evaluation Methods. California:

Pilli, Olga. Fanaeian, Yasemin and M.Musa Al-Momani. 2014. Investigating the Students' Attitude Toward the use of E-Learning in Girne American University International Journal of Business and Social Science Vol. 5, No. 5; April 2014. Kyrenia, TRNC via Mersin 10 Turke Sage Publication, Inc. 